\title{
Management of the Overseas Library:
}

\section{Florida State in Florence}

\author{
Theresa Huey-Stone, \\ Frederick Korn, Curator \\ Strozier Library \\ Florida State University \\ Tallahassee
}

The Florida State University established an overseas study center in Florence, Italy, in 1966, and followed in 1971 with the founding of another study center in London. More than 500 American colleges and universities operate or sponsor a foreign study program. ${ }^{1}$ One fairly distinctive feature of the FSU programs, however, is that the homecampus librarians run the overseas branch library. Every year the university library approves the application of one of its librarians for temporary assignment to the branch library in Florence.

For the librarian who accepts this appointment the resulting experience is an enriching one, both culturally and professionally. But the efficient operation of the overseas branch library is by no means an easy task. The fourteen librarians who have individually managed the University's Florence Library since 1966 have faced many problems in varying degrees. Our collective assessment, through the wisdom of hindsight, suggests certain strategies for resolving, or at least surviving, these problems.

Among the difficulties faced by the overseas librarian, first and foremost is the difficulty of having to function as the public services librarian, technical services librarian, library administrator, supply clerk, secretary, and clerk typist. Most often these duties are all performed by one librarian with the help of only part-time student assistants. A second problem results from the closer and more frequent social contact between staff, students, and faculty that is inherent in the study-center environment. These changes in the librarian/patron relationship may cause some friction in the librarian's enforcement of policies and rules. The third major difficulty arises from the library's location in a foreign country where the majority of people do not speak English. Business procedures, government regulations, standards of living, and social customs

\footnotetext{
${ }^{1}$ Marjorie A. Cohen, in Whole World Handbook, ed. by Margaret E. Sherman (New York: Council on International Educational Exchange, 1972), p.22. Other excellent sources of information include Gail A. Cohen, ed., Vacation Study Abroad (New York: Institute of International Education, 34th ed., 1983); and, by the same editor and publisher, U.S. College-Sponsored Programs Abroad (13th ed., 1983).
}

differ from those known to Americans; and even the well-traveled librarian is therefore not immune from culture shock.

For the typical academic librarian who normally functions in only one specialized area, making the transition to "total librarian" surely offers a challenge. One of our reference librarians, when describing her year in Florence, seldom fails to mention the sense of inadequacy that arose when she began cataloging duties at the overseas branch. One of our catalogers, on the other hand, required several months of hard experience in order to learn how to manage a reference question effectively. If the prospective overseas librarian is to deal with areas of librarianship unpracticed since graduate school or entry-level positions, it is important that this librarian receive at least minimal training in the particulars of unfamiliar library routines. The most useful preparation would include the thorough reading of the policies and procedures manual for the overseas branch library, conferring with previous overseas librarians, and consulting with colleagues for guidance in their area of expertise.

For example, a liaison librarian in the acquisitions section can review for the new overseas librarian current practices for ordering materials for overseas use. The circulation librarian of the home campus might suggest a procedure for dealing with unpaid fines or unreturned books. The director of the home-campus library, as well as clarifying the mandated responsibilities of the overseas librarian for collecting statistical data (including circulation, reference, cataloging, vacation and sick leave, etc.), can also suggest the areas of discretionary management open to the overseas librarian.

The development of a handbook for managing the overseas library is a large contributor to stability in assuring effective library operations. The Florida State University Florence Library does have a manual of policies and procedures, thoroughly revised in 1982. This manual incorporates the collective wisdom of past experience and defines the responsibilities of the overseas librarian. Like any standard library manual, this manual begins with a general statement of mission and goals. Then it broadly outlines the policies of the Florence Library regarding collections and services. The final section offers a very detailed account of the many procedures to follow in executing these policies. The section on cataloging, for example, provides extensive information for cataloging with or without OCLC cards. The process for soliciting new book orders from faculty is also given; and there are detailed procedures for acquiring materials, processing new books, handling circulation 


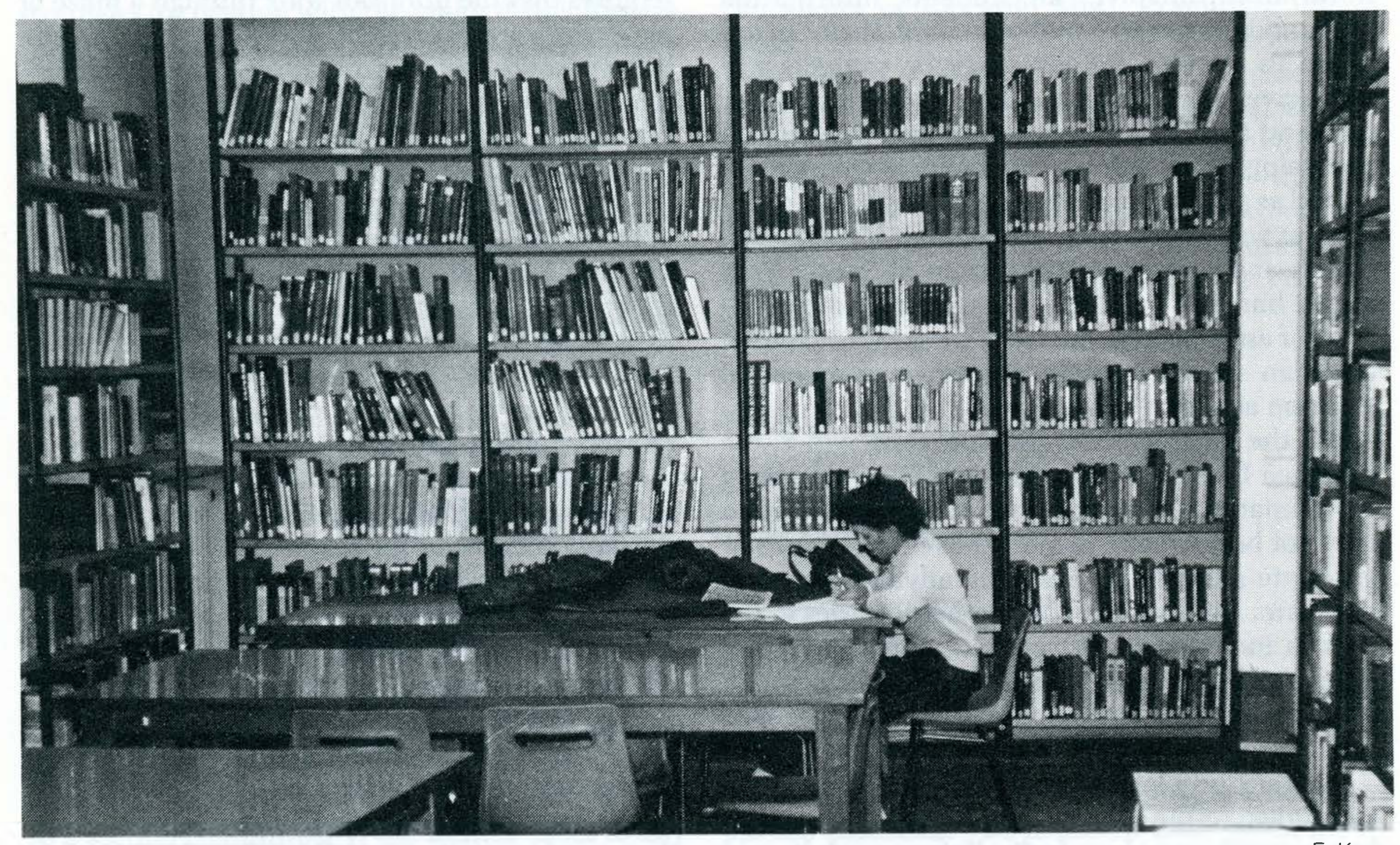

Florida State University's Florence Center Library.

and reserve book operations, and conducting an annual inventory of the collection. The manual also includes sample monthly reports, a sample time-schedule for library hours, and lists of Florence tradespeople who have been used for binding, book purchases, and even bookends! In short, the manual guides the overseas librarian by defining areas of responsibility and prerogative, and by describing the modus operandi for all areas of librarianship-technical services, general public services, and administrative duties.

In spite of advance preparation and procedure manuals, some librarians may still be overwhelmed by the demands of managing a library without the support they are accustomed to receiving from colleagues at home. This is largely a question of attitude and character and willingness on the part of the librarian to assume responsibility. As time passes (and for this reason we recommend an appointment of no less than one academic year) the librarian's skills and confidence usually increase. The end result is an excellent opportunity to show initiative and to exercise professional judgment. One former overseas librarian at Florida State University has called her Florence assignment "a most enlightening continuing-education experience."

The second major difficulty concerns the differences in librarian/patron relationships that develop owing to the relatively small number of staff and students in the study center, and the heightened amount of social interaction that occurs between faculty, students, and staff. Whereas the services of the home-campus library are largely impersonal, patrons at the overseas library are usu- ally known on a first-name basis; and the librarian may participate in group field trips and organized social events.

With the growing personal conversation that results, some students will argue for special favors-that the librarian overlook an overdue fine, that they be allowed to borrow restricted reference materials, that the librarian deliver personal messages or guard private possessions. Also the librarian may have to confront students who use the library for social purposes rather than for research or study. It is important that at the beginning of the term the librarian inform the students and faculty about library policies, and that these policies be enforced uniformly throughout the term. Although professional discretion may call for bending the rules under unusual circumstances, the librarian's personal relationship with any patron must never interfere with the role of authority that guarantees equal access of materials, fair and equal penalties for infringement of rules, and maintenance of a study environment. Related to this is the students' occasional request (or demand) for the extensive library hours to which they have become accustomed at the home-campus library. Again, at the beginning of each term the librarian must firmly state the limitations of staff time and describe how these limitations affect library hours. One solution is to allow a vote among the students: they choose between weekday evening hours or extended hours on the weekend before examinations. The librarian may also ration the work hours of the student assistants so as to permit extended hours during examination periods.

Another difference between home and overseas 
librarianship involves the students' information needs and the library's ability to fulfill them. In addition to research for term papers, students will seek travel information for their semester break or weekend trip. The Florence Library maintains an uncataloged collection of guidebooks (chiefly acquired as gifts) to museums, cities, and other countries, as well as extensive vertical files of travel brochures and maps that have been obtained from tourist bureaus. While the librarian may direct patrons or assist them in the use of these materials, the librarian should strongly discourage demands to function as a travel agent.

For the average undergraduate term paper, the Florence Library's collection of 6,000 volumes in the humanities is exceptional. But this collection may not be adequate to meet the research needs of graduate students or even the advanced undergraduate. Information about other libraries in the area is included in the policies and procedures manual, and the patron may also be referred to an English-language directory of libraries in the host city. $^{2}$

Another problem imposed on the librarian by the students is the occasional pressure to function in loco parentis or in loco fratis. Being an adult, and often the most accessible member of the staff, the librarian may be sought by students who need to unburden their problems-often the typical problems but aggravated by a foreign world. If the librarian is disposed to offer sympathy and advice, this should be done outside working hours, in order to minimize the disruption of the study environment and library routines. However, our experience has shown that a better solution is for the home university to provide an experienced counselor for the overseas center, perhaps a graduate student who has lived in the host city before.

But sometimes the librarian too needs a counselor! And this brings us to the final major difficulty faced by the overseas librarian-adapting to the foreign environment and dealing with language barriers.

From the American perspective the politics, economic structure, and social customs in Italy may sometimes seem eccentric. In practical terms this erects a formidable obstacle to the expeditious completion of ordinary business; few enterprises should be undertaken with the expectation of routine, smooth completion on schedule. For example, there is the problem of dealing with postal and customs officials. While most packages of the same kind of materials may be held (quite arbitrarily) at the city's Dogana (customs office); and the librarian may therefore be required to make two separate journeys to two separate agencies and then to wait ten to fifteen days for the materials to be delivered. Mailing packages to places outside Italy also

${ }^{2}$ For example, there is Virginia S. Caprio, Libraries in Florence (Florence: St. James American Church, 2d ed., 1975). requires that the librarian walk through a maze of paperwork and wrapping procedures; the business hours of shops, banks, post offices, etc., are not uniform; and any presupposition of continuity may be rudely disabused by an ad hoc workers' strike.

Advance knowledge of these conditions may do little towards changing them; but the prospective overseas librarian who receives adequate orientation and fair warning will undergo less stress and frustration, and may even develop a sense of humor as a helpful response to cultural differences. Former overseas librarians and the current overseas staff can be helpful in preparing the librarian on these matters and in giving important advice on such practical and personal needs as the location of a good laundry, the names of at least two Englishspeaking doctors, or the methods for staying warm in buildings heated to European norms. Without this information the librarian new to the overseas branch might well find the smooth completion of simple duties much more difficult than need be.

Obviously the librarian must negotiate business through the medium of a foreign language; except in high tourist-season one meets few natives who speak English. Explanations, clarifications, directions, and requests are delivered and received in Italian. This language barrier can be overwhelming and can create a sense of isolation and even panic. To prevent this kind of extreme reaction it is essential that the librarian learn (or relearn) the rudiments of the language before departing for the overseas center. College courses are certainly helpful, especially because structure and discipline are imposed upon the students. But conversational skills and the most practical uses of language (for example, how much? how do I get to? when does it open? why not?) will be more useful, at least for the beginner, than learning how to conjugate verbs in all tenses or how to manage the subtleties of mood and tense sequence in Italian complex sentences. There are several good self-programmed texts and cassette tapes available for this purpose. Perhaps the opportunity to engage a private tutor should be seriously considered. In spite of limited language skills, one former Florence librarian reports that her smile, politeness, and initial apology for not speaking the language well usually elicited patience and cooperation from Florentines.

There is one more source of assistance available to the overseas librarian that should not be overlooked: the librarian as a professional is not alone. Apart from the professional courtesies extended by the native librarians, English-speaking librarians employed by other American centers overseas may be helpful. (In Florence, for example, there are currently nine American college and university programs that operate their own library.) Book exchanges, advice on acquiring supplies and equipment, or reciprocal library-use privileges for patrons may be arranged. And certainly our compatriot librarians, many of whom may have lived in the host city for many years, can suggest 
strategies for dealing with the major difficulties already detailed and may offer to help the new librarian adjust to a foreign city.

Handling all library routines singlehandedly, coping with a different kind of librarian/patron relationship, and adjusting to foreign ways - these are the major problems that challenge the overseas librarian. Our overseas librarians also have cherished memories of wandering the ancient roads of Pompeii, attending symphonies conducted by $\mathrm{Zu}-$ bin Mehta or Riccardo Muti, examining illuminated manuscripts at the great Biblioteca MediceaLaurenziana (with its Michelangelo staircase), and enjoying many other events of cultural enrichment. But it is professional enrichment-the broadening of professional experience-that has been the most constant, and perhaps the most important, benefit derived by all the librarians who have managed the Florence branch library of Florida State University.

\section{ACRL Seeks Volunteers for Offices and Committees}

Would you like to run for an ACRL office or volunteer for appointment to an ACRL standing committee? Are you interested in seeking office in an ACRL section or being considered for appointment to a section committee? If the answer is yes to any of these questions, here is how you proceed.

\section{ACRL President}

The ACRL Appointments and Nominations Committee will nominate candidates for the office of ACRL vice-president/president-elect at the January 1984 Midwinter meeting of ALA. The election for this office will be held in the spring of 1985 . The winner of the election will serve as vicepresident/president-elect during 1985-86 and as president of ACRL during 1986-87. If you wish to be considered for nomination to this office or if you would like to submit names for consideration, contact the chair of the Appointments and Nominations Committee, Mary Reichel, Head, Reference Department, Pullen Library, Georgia State University, 100 Decatur Street, Atlanta, GA 30303.

\section{ACRL Committees}

ACRL has eighteen standing committees to which appointments may be made: Academic or Research Librarian of the Year Award Committee, Academic Status Committee, Appointments and Nominations Committee, Audiovisual Committee, Budget and Finance Committee, Conference Program Planning Committee, Constitution and Bylaws Committee, Continuing Education Committee Copyright Committee, Doctoral Disserta-

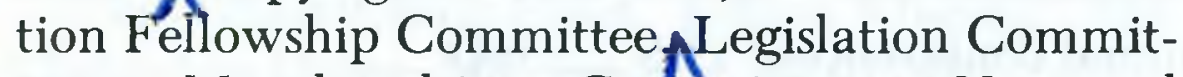
tee, Membership Committee, National Conference Committee, Planning Committee, Publications Committee, Samuel Lazerow Fellowship Committee, Standards and Accreditation Committee, and the Supplemental Funds Com-? mittee. To learn about the areas of responsibility covered by these committees, see the ALA Handbook of Organization 1983-84.
When selected vacancies occur on ACRL standing committees, the Appointments and Nominations Committee recommends to the presidentelect of ACRL the names of members who might fill the vacancies. The president-elect makes the final appointments. If you are interested in being considered for appointment to an ACRL committee, you should complete the ACRL Committee Volunteer Form that is included in this issue of C $\& R L$ News and mail it to Mary Reichel, chair of the Appointments and Nominations Committee, before January 1, 1984.

\section{ACRL Section Officers}

ACRL has thirteen sections (their names are listed later in this article). You will find a description of their areas of responsibility in the ALA Handbook of Organization.

The chair-elect of a section appoints the chair and members of all section committees when scheduled vacancies on these committees occur. If you would like to be considered for appointment as chair or member of a section committee, fill out the ACRL Committee Volunteer Form and mail it to the chair-elect of the appropriate section (see "People to Contact” below) before January 1, 1984.

\section{Editorial BoARDS}

ACRL has five editorial boards: the Choice Editorial Board, the College \& Research Libraries Editorial Board, the College \& Research Libraries News Editorial Board, the Nonprint Media Publications Editorial Board, and the Publications in Librarianship Editorial Board. When a vacancy occurs on an editorial board, the editor recommends the name of a person to fill the vacancy. The Publications Committee must approve the recommendation. The ACRL Board must give its approval, and finally the president of ACRL makes the appointment.

If you would like to be considered for appointment to an editorial board, contact the editor of the

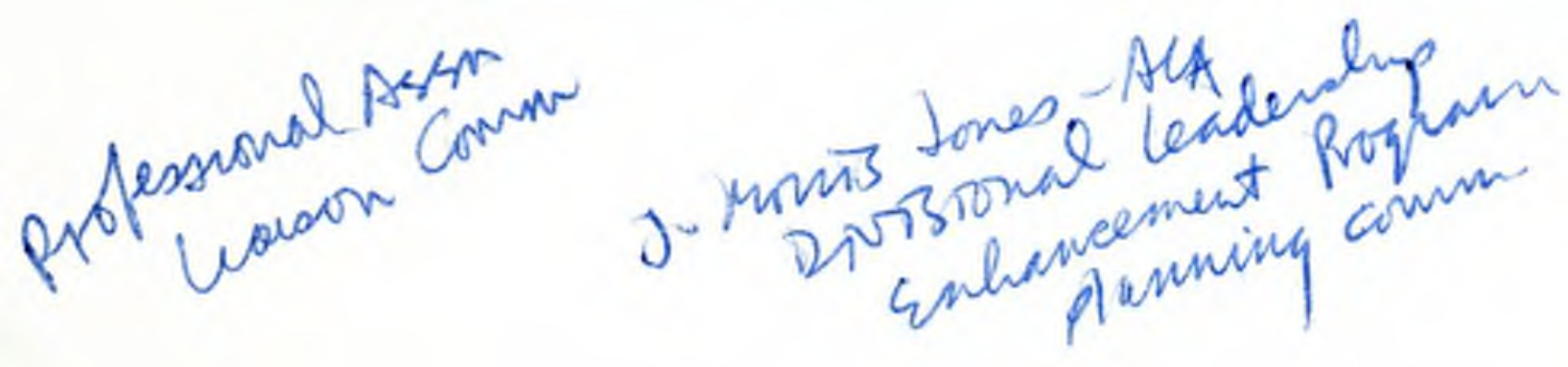

